\title{
Study on the Reactivity of Diarylmethane Derivatives in Supercritical Alcohols Media: Reduction of Diarylmethanols and Diaryl Ketones to Diarylmethanes Using Supercritical 2-Propanol
}

\author{
Bunpei Hatano, ${ }^{*}$ Daisuke Kubo, and Hideyuki Tagaya \\ Department of Chemistry and Chemical Engineering, Faculty of Engineering, Yamagata University; Jonan, Yonezawa \\ 992-8510, Japan. Received May 25, 2006; accepted June 16, 2006; published online June 30, 2006
}

\begin{abstract}
We found that diarylmethanols and diaryl ketones were smoothly reduced to the corresponding diarylalkanes using supercritical 2-propanol in good yields. Furthermore, we determined the specific reaction of fluorene using supercritical methanol at high temperature.
\end{abstract}

Key words supercritical 2-propanol; supercritical methanol; diarylmethanol; diaryl ketone; fluorene

Recently, the transformation of organic compounds using supercritical fluids as a reaction medium has received much attention in the field of organic synthesis. A great number of synthetic methods have been developed in supercritical carbon dioxide. ${ }^{1,2)}$ On the other hand, there have been only a few attempts using supercritical water and alcohol for synthetic applications due to their high critical temperature (supercritical water: $T_{\mathrm{c}}=374{ }^{\circ} \mathrm{C}$, supercritical methanol: $T_{\mathrm{c}}=239^{\circ} \mathrm{C}$, supercritical 2-propanol: $T_{\mathrm{c}}=235^{\circ} \mathrm{C}$ ). ${ }^{3-9)}$ However, the development of new synthetic approaches under supercritical conditions remains an attractive research area, since the use of water and alcohol is valuable not only for ecological and economical reasons but also for their unique physicochemical properties under supercritical conditions. ${ }^{10,11)}$ In our previous report, we revealed that supercritical water accelerates the disproportionation of diarylmethanol derivatives (1) to diarylmethanes (2) and diaryl ketones (3) (Eq. 1). ${ }^{12)}$

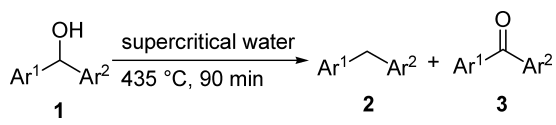

During the course of our studies on the reactivity of diarylmethane derivatives in alcohols at high-temperature, we found that diarylmethanols (1) and diaryl ketones (3) were reduced to the corresponding diarylalkanes (2) using supercritical 2-propanol in good yields. Furthermore, we found that fluorenes were transformed into 9-methylfluorenes in the presence of sodium methoxide under supercritical methanol.

\section{Experimental}

General The ${ }^{1} \mathrm{H}$ - and ${ }^{13} \mathrm{C}-\mathrm{NMR}$ spectra were measured by Varian Unity-Inova 500 or Mercury 200 spectrometers using TMS as the internal standard. Column chromatography was carried out using a Silica Gel $60 \mathrm{~N}$ (Kanto Kagaku). The TLC analysis was performed using a Kieselgel 60 F254 (Merck). All dry solvents were freshly distilled under nitrogen over the appropriate drying agent before use. The reagents were purchased from Kanto Kagaku and Aldrich Chemical Company.

Preparation of Isopropyl Diphenylmethyl Ether (4a) This compound was prepared by the literature method. ${ }^{13)}$ To a solution of benzhydrol (1a) $(1.84 \mathrm{~g}, 10 \mathrm{mmol})$ and 2-propanol $(3.8 \mathrm{ml}, 50 \mathrm{mmol})$ in 1,2-dichloroethane $(50 \mathrm{ml})$ at room temperature was added zinc chloride $(8.18 \mathrm{~g}, 60 \mathrm{mmol})$. The reaction mixture was stirred at room temperature for $5 \mathrm{~h}$. The usual workup and distillation with a Kugelrohr apparatus gave 4a in $41 \%$ yield $(922 \mathrm{mg}$, $4.1 \mathrm{mmol}) .4 \mathrm{a}:{ }^{1} \mathrm{H}-\mathrm{NMR}\left(\mathrm{CDCl}_{3}, 500 \mathrm{MHz}\right) \delta: 7.36-7.20(\mathrm{~m}, 10 \mathrm{H}), 5.47$ $(\mathrm{s}, 1 \mathrm{H}), 3.67(\mathrm{q}, 1 \mathrm{H}, J=6.5 \mathrm{~Hz}), 1.22(\mathrm{~d}, 6 \mathrm{H}, J=6.5 \mathrm{~Hz}) ;{ }^{13} \mathrm{C}-\mathrm{NMR}\left(\mathrm{CDCl}_{3}\right.$, $125 \mathrm{MHz}) \delta: 142.9,128.3,127.2,127.0,80.4,69.1,41.9,22.2$

A Typical Procedure for Reduction of Diarylmethanols (1) to Diaryl- methanes (2) Using 2-Propanol at $400^{\circ} \mathrm{C}$ In a tubular steel bomb reactor $(10 \mathrm{ml})$ were placed $1(2.0 \mathrm{mmol})$ and 2-propanol $(3.0 \mathrm{ml})$ under an argon atmosphere, and the reactor was sealed with a steel cap. The reactor was kept at $400{ }^{\circ} \mathrm{C}$ for $5 \mathrm{~h}$ in a sand bath. After the reactor was cooled to room temperature in a water bath, AcOEt $(30 \mathrm{ml})$ and $\mathrm{H}_{2} \mathrm{O}(20 \mathrm{ml})$ were added to the resulting mixture, and the two liquid layers were then separated. The organic layer was washed with brine $(20 \mathrm{ml})$, dried over $\mathrm{Na}_{2} \mathrm{SO}_{4}$, and concentrated under reduced pressure. The residue was purified by bulb-to-bulb distillation, giving 2 in the yield shown in Table 1 . The pressure at $400{ }^{\circ} \mathrm{C}$ was measured using an autoclave reactor with a manometer. When 1a $(368 \mathrm{mg}$, $2.0 \mathrm{mmol})$ and 2-propanol $(3.0 \mathrm{ml})$ were placed in the autoclave reactor $(10 \mathrm{ml})$, the pressure was $99-110 \mathrm{~kg} / \mathrm{cm}^{2}$ at $400{ }^{\circ} \mathrm{C}$. The pressure of other solvents was as follow: methanol $\left(121-153 \mathrm{~kg} / \mathrm{cm}^{2}\right)$, ethanol $(104-124$ $\left.\mathrm{kg} / \mathrm{cm}^{2}\right)$, tert-butanol $\left(87-116 \mathrm{~kg} / \mathrm{cm}^{2}\right) .2 \mathrm{a}:{ }^{1} \mathrm{H}-\mathrm{NMR}\left(\mathrm{CDCl}_{3}, 200 \mathrm{MHz}\right) \delta$ $7.25-7.19(\mathrm{~m}, 10 \mathrm{H}), 3.98(\mathrm{~s}, 2 \mathrm{H}) ;{ }^{13} \mathrm{C}-\mathrm{NMR}\left(\mathrm{CDCl}_{3}, 50 \mathrm{MHz}\right) \delta: 141.1$ $128.9,128.4,126.0,41.9$. 2b: ${ }^{1} \mathrm{H}-\mathrm{NMR}\left(\mathrm{CDCl}_{3}, 200 \mathrm{MHz}\right) \delta: 7.28-7.06$ $(\mathrm{m}, 9 \mathrm{H}), 3.91(\mathrm{~s}, 2 \mathrm{H}), 2.93(\mathrm{~s}, 3 \mathrm{H}) ;{ }^{13} \mathrm{C}-\mathrm{NMR}\left(\mathrm{CDCl}_{3}, 50 \mathrm{MHz}\right) \delta: 141.3$, 138.0, 135.4, 129.1, 128.8, 128.7, 128.3, 125.9, 41.4, 20.9. 2c: ${ }^{1} \mathrm{H}-\mathrm{NMR}$ $\left(\mathrm{CDCl}_{3}, 200 \mathrm{MHz}\right) \delta: 7.78-7.60(\mathrm{~m}, 3 \mathrm{H}), 7.60(\mathrm{~s}, 1 \mathrm{H}), 7.42-7.17(\mathrm{~m}$ $8 \mathrm{H}), 4.10(\mathrm{~s}, 2 \mathrm{H}) ;{ }^{13} \mathrm{C}-\mathrm{NMR}\left(\mathrm{CDCl}_{3}, 50 \mathrm{MHz}\right) \delta: 140.9,138.5,133.6,132.0$, $129.0,128.3,128.0,127.6,127.3,127.1,126.7,126.0,125.7,125.4,42.1$. 2d: ${ }^{1} \mathrm{H}-\mathrm{NMR}\left(\mathrm{CDCl}_{3}, 200 \mathrm{MHz}\right) \delta: 8.50-8.47(\mathrm{~m}, 2 \mathrm{H}), 7.32-7.08(\mathrm{~m}$ $7 \mathrm{H}), 3.96(\mathrm{~s}, 2 \mathrm{H}) ;{ }^{13} \mathrm{C}-\mathrm{NMR}\left(\mathrm{CDCl}_{3}, 50 \mathrm{MHz}\right) \delta: 149.9,149.6,138.7,128.9$, 128.6, 126.5, 124.0, 41.1

A Typical Procedure for Direct Reduction of Diaryl Ketones (3) to Diarylmethanes (2) Using 2-Propanol at $350^{\circ} \mathrm{C}$ In a tubular steel bomb reactor $(10 \mathrm{ml})$ were placed $3(2.0 \mathrm{mmol})$ and 2-propanol $(5.0 \mathrm{ml})$ under an argon atmosphere, and the reactor was sealed with an steel cap. The reactor was kept at $350^{\circ} \mathrm{C}$ for $5 \mathrm{~h}$ in a sand bath. After the reactor was cooled to room temperature in a water bath, AcOEt $(30 \mathrm{ml})$ and $\mathrm{H}_{2} \mathrm{O}(20 \mathrm{ml})$ were added to the resulting mixture, and the two liquid layers were then separated. The organic layer was washed with brine $(20 \mathrm{ml})$, dried over $\mathrm{Na}_{2} \mathrm{SO}_{4}$, and concentrated under reduced pressure. The residue was purified by bulb-tobulb distillation, giving $\mathbf{2}$ in the yield shown in Table 2 . The pressure at described temperature was measured using an autoclave reactor with a manometer. When 3a $(364 \mathrm{mg}, 2.0 \mathrm{mmol})$ and 2-propanol $(5.0 \mathrm{ml})$ were placed in the autoclave reactor $(10 \mathrm{ml})$, the pressure was $125-143 \mathrm{~kg} / \mathrm{cm}^{2}$ at $350{ }^{\circ} \mathrm{C}$. The pressure at other temperatures was as follows: $250{ }^{\circ} \mathrm{C}(45-$ $\left.52 \mathrm{~kg} / \mathrm{cm}^{2}\right), 300{ }^{\circ} \mathrm{C}\left(62-67 \mathrm{~kg} / \mathrm{cm}^{2}\right) .2 \mathrm{e}:{ }^{1} \mathrm{H}-\mathrm{NMR}\left(\mathrm{CDCl}_{3}, 200 \mathrm{MHz}\right) \delta$ $7.15-6.99(\mathrm{~m}, 9 \mathrm{H}), 3.87(\mathrm{~s}, 2 \mathrm{H}), 2.12(\mathrm{~s}, 3 \mathrm{H}) ;{ }^{13} \mathrm{C}-\mathrm{NMR}\left(\mathrm{CDCl}_{3}, 50 \mathrm{MHz}\right)$ $\delta: 140.3,138.9,136.6,130.2,129.9,128.9,128.7,128.3,125.9,125.7,39.4$ 19.6. 2f: ${ }^{1} \mathrm{H}-\mathrm{NMR}\left(\mathrm{CDCl}_{3}, 200 \mathrm{MHz}\right) \delta$ : $7.21-6.98(\mathrm{~m}, 9 \mathrm{H}), 3.91(\mathrm{~s}, 2 \mathrm{H})$ $2.28(\mathrm{~s}, 3 \mathrm{H}) ;{ }^{13} \mathrm{C}-\mathrm{NMR}\left(\mathrm{CDCl}_{3}, 50 \mathrm{MHz}\right) \delta: 141.2,141.0,137.9,129.7$ 128.9, 128.9, 128.4, 128.3, 126.8, 126.0, 41.8, 21.4. 2g: ${ }^{1} \mathrm{H}-\mathrm{NMR}\left(\mathrm{CDCl}_{3}\right.$ $200 \mathrm{MHz}) \delta: 7.05-7.04(\mathrm{~m}, 8 \mathrm{H}), 3.86(\mathrm{~s}, 2 \mathrm{H}), 2.27(\mathrm{~s}, 6 \mathrm{H}) ;{ }^{13} \mathrm{C}-\mathrm{NMR}$ $\left(\mathrm{CDCl}_{3}, 50 \mathrm{MHz}\right) \delta: 138.3,135.3,129.1,128.7,41.0,20.9 .2 \mathbf{h}:{ }^{1} \mathrm{H}-\mathrm{NMR}$ $\left(\mathrm{CDCl}_{3}, 200 \mathrm{MHz}\right) \delta: 7.81-7.77(\mathrm{~m}, 2 \mathrm{H}), 7.56-7.52(\mathrm{~m}, 2 \mathrm{H}), 7.41-7.23$ $(\mathrm{m}, 4 \mathrm{H}), 3.90(\mathrm{~s}, 2 \mathrm{H}) ;{ }^{13} \mathrm{C}-\mathrm{NMR}\left(\mathrm{CDCl}_{3}, 50 \mathrm{MHz}\right) \delta: 143.1,141.6,126.6$ 126.6, 125.0, 119.8, 36.8. 2i: ${ }^{1} \mathrm{H}-\mathrm{NMR}\left(\mathrm{CDCl}_{3}, 200 \mathrm{MHz}\right) \delta: 7.18-7.07(\mathrm{~m}$ $4 \mathrm{H}), 2.89(\mathrm{~m}, 4 \mathrm{H}), 2.04(\mathrm{~m}, 2 \mathrm{H}) ;{ }^{13} \mathrm{C}-\mathrm{NMR}\left(\mathrm{CDCl}_{3}, 50 \mathrm{MHz}\right) \delta: 144.0$ 126.0, 124.3, 32.9, 25.3. 2j: ${ }^{1} \mathrm{H}-\mathrm{NMR}\left(\mathrm{CDCl}_{3}, 200 \mathrm{MHz}\right) \delta: 7.60-7.22(\mathrm{~m}$ $9 \mathrm{H}), 2.38(\mathrm{~s}, 3 \mathrm{H}) ;{ }^{13} \mathrm{C}-\mathrm{NMR}\left(\mathrm{CDCl}_{3}, 50 \mathrm{MHz}\right) \delta: 141.1,138.3,136.9,129.4$ $128.8,128.7,126.9,126.9,21.1$. 
The Reaction of Isopropyl Diphenylmethyl Ether (4a) Using 2Propanol at $350{ }^{\circ} \mathbf{C}$ In a tubular steel bomb reactor $(10 \mathrm{ml})$ were placed $4 \mathbf{a}$ $(453 \mathrm{mg}, 2.0 \mathrm{mmol})$ and 2-propanol $(5.0 \mathrm{ml})$ under an argon atmosphere, and the reactor was sealed with an steel cap. The reactor was kept at $350{ }^{\circ} \mathrm{C}$ for $5 \mathrm{~h}$ in a sand bath. After the reactor was cooled to room temperature in a water bath, AcOEt $(30 \mathrm{ml})$ and $\mathrm{H}_{2} \mathrm{O}(20 \mathrm{ml})$ were added to the resulting mixture, and the two liquid layers were then separated. The organic layer was washed with brine $(20 \mathrm{ml})$, dried over $\mathrm{Na}_{2} \mathrm{SO}_{4}$, and concentrated under reduced pressure. The residue was purified by column chromatography on silica gel (hexane-AcOEt as the eluent) to afford 2a (334 mg, 99\%).

The transformation of Fluorenes ( $2 \mathrm{~h}, 2 \mathrm{k}$, and $2 \mathrm{l})$ to 9-Methylfluorenes (5) Using Methanol at $450{ }^{\circ} \mathrm{C}$ In a tubular steel bomb reactor $(10 \mathrm{ml})$ were placed $2(2.0 \mathrm{mmol})$, sodium methoxide $(270 \mathrm{mg}, 5.0 \mathrm{mmol})$ and methanol $(3.0 \mathrm{ml})$ under an argon atmosphere, and the reactor was sealed with a steel cap. The reactor was kept at $450{ }^{\circ} \mathrm{C}$ for $5 \mathrm{~h}$ in a sand bath. After the reactor was cooled to room temperature in a water bath, AcOEt $(30 \mathrm{ml})$ and $\mathrm{H}_{2} \mathrm{O}(20 \mathrm{ml})$ were added to the resulting mixture, and the two liquid layers were then separated. The organic layer was washed with saturated $\mathrm{NaHCO}_{3}(20 \mathrm{ml})$ and brine $(20 \mathrm{ml})$, dried over $\mathrm{Na}_{2} \mathrm{SO}_{4}$, and concentrated under reduced pressure. The residue was purified by column chromatography on silica gel, giving the 9-methylfluorene (5) in the yield shown in Table 3. 5a: ${ }^{1} \mathrm{H}-\mathrm{NMR}\left(\mathrm{CDCl}_{3}, 500 \mathrm{MHz}\right) \delta: 7.79-7.74(\mathrm{~m}, 2 \mathrm{H}), 7.55-7.49(\mathrm{~m}$, $2 \mathrm{H}), 7.38-7.28(\mathrm{~m}, 4 \mathrm{H}), 3.94(\mathrm{q}, 1 \mathrm{H}, J=7.6 \mathrm{~Hz}), 1.52(\mathrm{~d}, 3 \mathrm{H}, J=7.6 \mathrm{~Hz})$ ${ }^{13} \mathrm{C}-\mathrm{NMR}\left(\mathrm{CDCl}_{3}, 125 \mathrm{MHz}\right) \delta: 149.1,140.6,127.0,126.7,124.0,119.8$, 42.4, 18.2. 5b: ${ }^{1} \mathrm{H}-\mathrm{NMR}\left(\mathrm{CDCl}_{3}, 500 \mathrm{MHz}\right) \delta: 7.69(\mathrm{~d}, 1 \mathrm{H}, J=7.5 \mathrm{~Hz}), 7.64$ $(\mathrm{d}, 1 \mathrm{H}, J=7.5 \mathrm{~Hz}), 7.46(\mathrm{~d}, 1 \mathrm{H}, J=8.0 \mathrm{~Hz}), 7.37-7.27(\mathrm{~m}, 3 \mathrm{H}), 7.15(\mathrm{~d}, 1 \mathrm{H}$, $J=8.0 \mathrm{~Hz}), 3.83(\mathrm{q}, 1 \mathrm{H}, J=7.5 \mathrm{~Hz}), 2.42(\mathrm{~s}, 3 \mathrm{H}), 1.49(\mathrm{~d}, 3 \mathrm{H}, J=7.5 \mathrm{~Hz})$ ${ }^{13} \mathrm{C}-\mathrm{NMR}\left(\mathrm{CDCl}_{3}, 125 \mathrm{MHz}\right) \delta: 149.2,148.8,140.5,137.8,136.7,127.7$, $126.8,126.6,126.4,124.7,123.9,119.5,42.2,21.6,18.2 .5 \mathbf{c}:{ }^{1} \mathrm{H}-\mathrm{NMR}$ $\left(\mathrm{CDCl}_{3}, 500 \mathrm{MHz}\right) \delta: 7.62-7.58(\mathrm{~m}, 2 \mathrm{H}), 7.45-7.40(\mathrm{~m}, 1 \mathrm{H}), 7.33-7.14$ $(\mathrm{m}, 2 \mathrm{H}), 6.86(\mathrm{~s}, 1 \mathrm{H}), 6.77-6.61(\mathrm{~m}, 1 \mathrm{H}), 3.87(\mathrm{q}, 1 \mathrm{H}, J=7.4 \mathrm{~Hz}), 3.00(\mathrm{~s}$ $6 \mathrm{H}), 1.50(\mathrm{~d}, 3 \mathrm{H}, J=7.4 \mathrm{~Hz}) ;{ }^{13} \mathrm{C}-\mathrm{NMR}\left(\mathrm{CDCl}_{3}, 125 \mathrm{MHz}\right) \delta: 150.6,150.3$, $148.1,141.1,129.7,125.7,124.9,123.6,120.4,118.4,111.6,108.1,42.4$, 41.0, 18.5 .

The Reaction of Fluorenes (2h) with Formaldehyde at High Temperature In a tubular steel bomb reactor $(10 \mathrm{ml})$ were placed $2 \mathbf{h}(332 \mathrm{mg}$, $2.0 \mathrm{mmol})$, sodium methoxide $(270 \mathrm{mg}, 5.0 \mathrm{mmol})$ and an aqueous solution of formaldehyde $(37 \mathrm{w} \%, 3.0 \mathrm{ml})$ under an argon atmosphere. The reactor was sealed with a steel cap. The reactor was kept at $450{ }^{\circ} \mathrm{C}$ for $5 \mathrm{~h}$ in a sand bath. After the reactor was cooled to room temperature in a water bath, AcOEt $(30 \mathrm{ml})$ and $\mathrm{H}_{2} \mathrm{O}(20 \mathrm{ml})$ were added to the resulting mixture, and the two liquid layers were then separated. The organic layer was washed with saturated $\mathrm{NaHCO}_{3}(20 \mathrm{ml})$ and brine $(20 \mathrm{ml})$, dried over $\mathrm{Na}_{2} \mathrm{SO}_{4}$, and concentrated under reduced pressure. The residue was purified by column chromatography on silica gel $(30 \mathrm{~g}$, petroleum ether : chloroform $=50: 0,48: 2$, $46: 4,44: 6,42: 8,40: 10,35: 15,30: 20,25: 25$, and $0: 50$ each $\times 50 \mathrm{ml}$ ), giving the 9-methylfluorene (5a) in the yield shown in Table 4 , entry 1 .

The Reaction of Fluorenes (2h) with Benzaldehyde Derivatives at High Temperature In a tubular steel bomb reactor $(10 \mathrm{ml})$ were placed $\mathbf{2 h}$ $(332 \mathrm{mg}, 2.0 \mathrm{mmol})$, sodium methoxide $(270 \mathrm{mg}, 5.0 \mathrm{mmol})$ and the benzaldehyde derivative $(3 \mathrm{ml})$ under an argon atmosphere. The reactor was sealed with a steel cap. The reactor was kept at $350{ }^{\circ} \mathrm{C}$ for $5 \mathrm{~h}$ in a sand bath. After the reactor was cooled to room temperature in a water bath, toluene $(30 \mathrm{ml})$ and $\mathrm{H}_{2} \mathrm{O}(20 \mathrm{ml})$ were added to the resulting mixture, and the two liquid layers were then separated. The organic layer was washed with saturated $\mathrm{NaHCO}_{3}(20 \mathrm{ml})$ and brine $(20 \mathrm{ml})$, dried over $\mathrm{Na}_{2} \mathrm{SO}_{4}$, and concentrated under reduced pressure. After removal of the excess benzaldehyde by bulb-to-bulb distillation, the residue was purified by column chromatography on silica gel $(30 \mathrm{~g}$, petroleum ether : chloroform $=50: 0,48: 2,46: 4$, $44: 6,42: 8,40: 10,35: 15,30: 20,25: 25$, and $0: 50$ each $\times 50 \mathrm{ml}$ ), giving 9-benzylfluorenes $(\mathbf{7 a}, 7 \mathbf{b})$ in the yield shown in Table 4, entries 2 and 3. 7a: ${ }^{1} \mathrm{H}-\mathrm{NMR}\left(\mathrm{CDCl}_{3}, 500 \mathrm{MHz}\right) \delta: 7.69-7.15(\mathrm{~m}, 13 \mathrm{H}), 4.23(\mathrm{t}, 1 \mathrm{H}, J=7.7 \mathrm{~Hz})$, $3.10(\mathrm{~d}, 2 \mathrm{H}, J=7.7 \mathrm{~Hz}) ;{ }^{13} \mathrm{C}-\mathrm{NMR}\left(\mathrm{CDCl}_{3}, 125 \mathrm{MHz}\right) \delta: 146.8,140.8,139.8$, $129.5,128.3,127.0,126.6,124.6,119.8,49.7,40.1 .7 \mathbf{b}:{ }^{1} \mathrm{H}-\mathrm{NMR}\left(\mathrm{CDCl}_{3}\right.$, $500 \mathrm{MHz}) \delta: 7.29-7.07(\mathrm{~m}, 12 \mathrm{H}), 4.20(\mathrm{t}, 1 \mathrm{H}, J=7.4 \mathrm{~Hz}), 3.06(\mathrm{~d}, 2 \mathrm{H}$, $J=7.4 \mathrm{~Hz}), 2.44(\mathrm{~s}, 3 \mathrm{H}) ;{ }^{13} \mathrm{C}-\mathrm{NMR}\left(\mathrm{CDCl}_{3}, 125 \mathrm{MHz}\right) \delta: 146.9,140.8$, 129.3, 129.1, 128.9, 128.7, 127.0, 126.6, 124.8, 119.7, 48.7, 39.6, 21.1 .

The registry numbers are as follows: diphenylmethanol (1a) 91-01-0, (4-methylphenyl)(phenyl)methanol (1b) 1517-63-1, (2-naphtyl)(phenyl)methanol (1c) 35060-38-9, (phenyl)(4-pyridyl)methanol (1d) 33974-27-5, diphenylmethane (2a) 101-81-5, (4-methylphenyl)(phenyl)methane (2b) 620-83-7, (2-naphtyl)(phenyl)methane (2c) 613-59-2, (phenyl)(4-pyridyl)methane (2d) 2116-65-6, (2-methylphenyl)(phenyl)methane (2e) 713-36-0, (3-methylphenyl)(phenyl)methane (2f) 620-47-3, di(4-methylphenyl)- methane (2g) 4957-14-6, fluorene (2h) 86-73-7, indan (2i) 496-11-7, 4methylbiphenyl (2j) 644-08-6, 2-methylfluorene (2k) 1430-97-3, $N, N$-dimethyl-2-aminofluorene (2I) 13261-62-6, benzophenone (3a) 119-61-9, (4methylphenyl) phenyl ketone (3b) 643-65-2, (2-naphthyl) phenyl ketone (3c) 644-13-3, phenyl (4-pyridyl) ketone (3d) 14548-46-0, (2-methylphenyl) phenyl ketone (3e) 131-58-8, (3-methylphenyl) phenyl ketone (3f) 643-65-2, di(4-methylphenyl) ketone (3g) 611-97-2, fluorenone (3h) 486-25-9, indanone (3i) 83-33-0, 4-biphenylcarboxaldehyde (3j) 3218-36-8, isopropyl diphenylmethyl ether (4a) 5670-79-1, 9-methylfluorene (5a) 2523-37-7, 2,9dimethylfluorene (5b) 1430-97-3, 2-amino- $N, N, 9$-trimethylfluorene (5c) 727415-21-6, 9-benzylfluorene (7a) 1572-46-9, 9-(4-methylbenzyl)fluorene (7b) 745809-62-5.

\section{Results and Discussion}

Reaction of Diarylmethanols in Alcohol Medium under Supercritical Conditions We first examined the reactivity of diarylmethanols (1) in several alcohols under supercritical conditions (Eq. 2, Table 1). When 1a was treated with methanol at $400{ }^{\circ} \mathrm{C}$ for $5 \mathrm{~h}$, the direct reduction was smoothly performed to give the corresponding alkane $\mathbf{2 a}$ as a single product in $79 \%$ yield (entry 1 ). It was interesting to note that ketone 3a was not observed at all, as compared with the reaction of 1a in supercritical water. ${ }^{12)}$ In ethanol, the reduction of $\mathbf{1 a}$ also proceeded to give $\mathbf{2 a}$ in $83 \%$ yield (entry 2 ). The best result was obtained when the reaction was carried out using 2-propanol (entry 3). On the other hand, the reduction of 1a in tert-butanol proceeded with great difficulty; ketone (3a) was obtained as the main product (35\%) along with $\mathbf{2 a}$ $(27 \%)$ (entry 4$)$. These facts suggested that the hydrogen at the $\alpha$-position of the alcohol medium plays an important role in the reduction of $\mathbf{1}$. This reduction also smoothly proceeded in the case of the substrate bearing 4-methyl (1b), 2-naphtyl (1c), and 4-pyridyl (1d) groups (entries 5, 6, and 7, respectively).

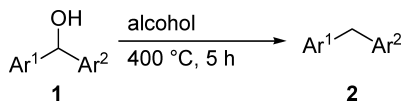

Reaction of Diaryl Ketones in 2-Propanol under Supercritical Conditions As the reduction of diarylmethanol (1) to diarylalkane (2) quite smoothly proceeded without the formation of diaryl ketone (3) in 2-propanol under supercritical conditions, we next studied the reactivity of diaryl ketone (3) in 2-propanol at high temperatures. ${ }^{14)}$ When ketone 3a was reacted with 2-propanol at $350^{\circ} \mathrm{C}$ for $5 \mathrm{~h}$, alkane $2 \mathrm{a}$ was obtained as a single product in good yield (Eq. 3 and Table 2, entry 1). The influence of temperature on this reduction was then investigated. The reduction of $\mathbf{1 a}$ did not proceed at $250^{\circ} \mathrm{C}$, and the unchanged $\mathbf{3 a}$ was recovered in quantitative yield (entry 2 ). Although the reduction of 1 a proceeded at $300{ }^{\circ} \mathrm{C}$, the product selectivity was not observed; alcohol 1a

Table 1. Reduction of $\mathbf{1}$ to $\mathbf{2}$ in Several Alcohols at $400{ }^{\circ} \mathrm{C}$

\begin{tabular}{ccllll}
\hline \hline Entry & $\mathbf{1}$ & \multicolumn{1}{c}{$\mathrm{Ar}^{1}$} & \multicolumn{1}{c}{$\mathrm{Ar}^{2}$} & Alcohol & Yield of 2 (\%) $)^{a)}$ \\
\hline 1 & $\mathbf{1 a}$ & $\mathrm{C}_{6} \mathrm{H}_{5}$ & $\mathrm{C}_{6} \mathrm{H}_{5}$ & $\mathrm{MeOH}$ & 79 \\
2 & $\mathbf{1 a}$ & $\mathrm{C}_{6} \mathrm{H}_{5}$ & $\mathrm{C}_{6} \mathrm{H}_{5}$ & EtOH & 83 \\
3 & $\mathbf{1 a}$ & $\mathrm{C}_{6} \mathrm{H}_{5}$ & $\mathrm{C}_{6} \mathrm{H}_{5}$ & $i-\mathrm{PrOH}$ & 95 \\
4 & $\mathbf{1 a}$ & $\mathrm{C}_{6} \mathrm{H}_{5}$ & $\mathrm{C}_{6} \mathrm{H}_{5}$ & $t-\mathrm{BuOH}$ & $27^{b)}$ \\
5 & $\mathbf{1 b}$ & $\mathrm{C}_{6} \mathrm{H}_{5}$ & $4-\mathrm{MeC}_{6} \mathrm{H}_{4}$ & $i-\mathrm{PrOH}$ & 91 \\
6 & $\mathbf{1 c}$ & $\mathrm{C}_{6} \mathrm{H}_{5}$ & 2-naphtyl & $i-\mathrm{PrOH}$ & 87 \\
7 & $\mathbf{1 d}$ & $\mathrm{C}_{6} \mathrm{H}_{5}$ & 4-pyridyl & $i-\mathrm{PrOH}$ & 90
\end{tabular}

a) Isolated yield. b) Ketone 3 a was obtained in $35 \%$ yield. 
and alkane $2 \mathrm{a}$ were obtained in $28 \%$ and $34 \%$ yields, respectively (entry 3 ). The alcohol medium also affected the product yield and selectivity, and the results in other alcohols were as follows: methanol (1a, 6\% yield, 2a, 12\% yield), ethanol (1a, 74\% yield, 2a, trace), tert-butanol (1a, $0 \%$ yield, 2a, $0 \%$ yield). This direct reduction using supercritical 2propanol was effective for other diaryl ketones (3). A similar treatment of diaryl ketones $(3 \mathbf{b}-\mathbf{i})$ with 2-propanol gave the corresponding diarylmethanes (2) in moderate to good yields (entries 4-11). In addition, aryl aldehyde (3j) was found to give the desirable alkane $\mathbf{2} \mathbf{j}$ in $85 \%$ yield after a longer reaction time (entry 12).

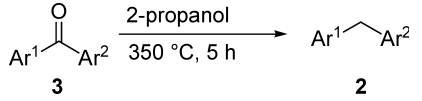

Table 2. Reduction of $\mathbf{3}$ to $\mathbf{2}$ in 2-Propanol at $350^{\circ} \mathrm{C}$

\begin{tabular}{|c|c|c|c|c|}
\hline Entry & 3 & $\mathrm{Ar}^{1}$ & $\mathrm{Ar}^{2}$ & Yield of $\mathbf{2}(\%)^{a)}$ \\
\hline 1 & $3 \mathbf{a}$ & $\mathrm{C}_{6} \mathrm{H}_{5}$ & $\mathrm{C}_{6} \mathrm{H}_{5}$ & 96 \\
\hline $2^{b)}$ & $3 \mathbf{a}$ & $\mathrm{C}_{6} \mathrm{H}_{5}$ & $\mathrm{C}_{6} \mathrm{H}_{5}$ & $0^{c)}$ \\
\hline $3^{d)}$ & $3 \mathbf{a}$ & $\mathrm{C}_{6} \mathrm{H}_{5}$ & $\mathrm{C}_{6} \mathrm{H}_{5}$ & $34^{e, f f}$ \\
\hline 4 & $3 e$ & $\mathrm{C}_{6} \mathrm{H}_{5}$ & $2-\mathrm{MeC}_{6} \mathrm{H}_{5}$ & 91 \\
\hline 5 & $3 f$ & $\mathrm{C}_{6} \mathrm{H}_{5}$ & $3-\mathrm{MeC}_{6} \mathrm{H}_{4}$ & 95 \\
\hline 6 & $\mathbf{3 b}$ & $\mathrm{C}_{6} \mathrm{H}_{5}$ & 4- $\mathrm{MeC}_{6} \mathrm{H}_{4}$ & 92 \\
\hline 7 & $3 g$ & 4- $\mathrm{MeC}_{6} \mathrm{H}_{4}$ & 4- $\mathrm{MeC}_{6} \mathrm{H}_{4}$ & 93 \\
\hline 8 & $3 c$ & $\mathrm{C}_{6} \mathrm{H}_{5}$ & 2-naphtyl & 90 \\
\hline 9 & 3d & $\mathrm{C}_{6} \mathrm{H}_{5}$ & 4-pyridyl & 89 \\
\hline 10 & $3 \mathrm{~h}$ & & & 85 \\
\hline 11 & $3 \mathbf{i}$ & & & 50 \\
\hline $12^{g)}$ & $3 \mathbf{j}$ & 4- $\mathrm{PhC}_{6} \mathrm{H}_{4}$ & $\mathrm{H}$ & 85 \\
\hline
\end{tabular}

a) Isolated yield. b) At $250^{\circ} \mathrm{C}$. c) Unchanged 3a was recovered in quantitative yield. d) At $300{ }^{\circ} \mathrm{C}$. e) 1 a was obtained in $28 \%$ yield. $f$ ) A trace amount of 4 a was detected by ${ }^{1} \mathrm{H}-\mathrm{NMR}$. g) For $10 \mathrm{~h}$.

Based on these results, the formation of an alkane $\mathbf{2}$ can be verified to proceed through the pathway shown in Chart 1: ketone 3 was initially transformed into alcohol 1 by MPV-reduction using supercritical 2-propanol, ${ }^{15-18)}$ and the subsequent ether $\mathbf{4}$ was formed from $\mathbf{1}$ and excess 2-propanol, and alkene 2 was produced by disproportionation of ether 4 . Indeed, a trace amount of isopropyl diphenyl ether (4a) was detected by ${ }^{1} \mathrm{H}-\mathrm{NMR}$ in the reaction of $\mathbf{2 a}$ using 2-propanol at $300^{\circ} \mathrm{C}$, and a similar treatment of ether $4 \mathbf{a}$ with 2-propanol gave alkane $\mathbf{2 a}$ in almost quantitative yield.

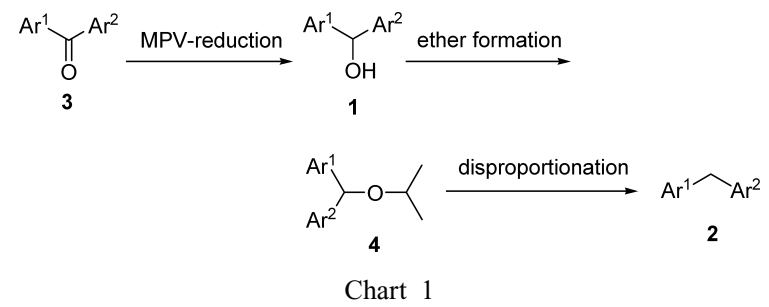

Reaction of Fluorenes in Supercritical Methanol During the course of our study on the reactivity of diarylmethane derivatives in an alcohol medium, we found that diarylmethanols (1) and diaryl ketones (3) were transformed into the corresponding diarylalkanes (2) using an alcohol having $\alpha$-hydrogen. We also found that several diarylalkanes (2) were inert in high-temperature alcohol medium. In the treatment of fluorenes with methanol, however, we observed the specific reaction of fluorene with methanol (Eq. 4).

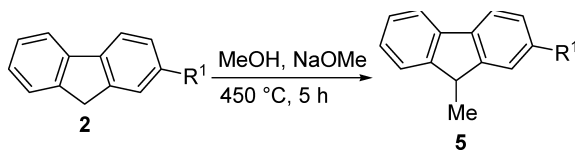

Table 3. Reaction of 2 Using Methanol in the Presence of $\mathrm{NaOMe}$ at $450^{\circ} \mathrm{C}$

\begin{tabular}{lllc}
\hline \hline Entry & $\mathbf{2}$ & \multicolumn{1}{c}{$\mathrm{R}^{1}$} & Yield of $\mathbf{5}(\%)^{a)}$ \\
\hline $1^{b)}$ & $\mathbf{2 h}$ & $\mathrm{H}$ & 42 \\
$2^{b, c)}$ & $\mathbf{2 h}$ & $\mathrm{H}$ & 0 \\
$3^{b, d)}$ & $\mathbf{2 h}$ & $\mathrm{H}$ & 14 \\
4 & $\mathbf{2 h}$ & $\mathrm{H}$ & 98 \\
$5^{e)}$ & $\mathbf{2 h}$ & $\mathrm{H}$ & 76 \\
6 & $\mathbf{2 k}$ & $\mathrm{CH}_{3}$ & 90 \\
$7^{f)}$ & $\mathbf{2 l}$ & $\left.\mathrm{N}^{(\mathrm{C}} \mathrm{H}_{3}\right)_{2}$ & 57
\end{tabular}

a) Isolated yield. b) In the absence of NaOMe. c) At $350{ }^{\circ} \mathrm{C}$. d) At $400^{\circ} \mathrm{C}$ e) $\mathrm{CD}_{3} \mathrm{OD}$ and $\mathrm{NaOCD}_{3}$ was used. f) For $2 \mathrm{~h}$.

When fluorene $2 \mathbf{h}$ was conducted with methanol at $450{ }^{\circ} \mathrm{C}$ for $5 \mathrm{~h}$, surprisingly, 9-methylfluorene (5a) was obtained in $42 \%$ yield along with the unchanged $\mathbf{2 h}$ (Table 3, entry 1 ). The reaction temperature affected the yield of 5a: the methylation of $\mathbf{2 h}$ took place only at slightly below $450{ }^{\circ} \mathrm{C}$ (entries $2,3)$. The addition of sodium methoxide improved the product yield to give 5a in $98 \%$ yield (entry 4 ). The methyl group at the 9-position was found to be from the methanol; when $2 \mathbf{h}$ was treated with deuterated methanol in the presence of sodium deuteroxide, fluorene (5a) bearing the deuterated methyl group at the 9-position was obtained in $76 \%$ yield (entry 5). Other fluorene derivatives $(\mathbf{2 k}, \mathbf{2 l})$ were transformed into the corresponding 9-methyl product $(\mathbf{5 b}, \mathbf{5 c})$ in $90 \%$ and $57 \%$ yields, respectively (entries 6,7 ). This methylation is specific for fluorene derivatives, since other arylalkanes, such as diphenylmethane, triphenylmethane, 9,10dihydroanthracene, and 10,11-dihydro-5H-dibenzo[a,d]cycloheptene, did not react at all.

Although the detailed pathway is not clear in this specific reaction, the methylation of fluorenes seemed to be triggered by the nucleophilic addition of the fluorene anion with formaldehyde which was produced by disproportionation of methanol as shown in Chart 2: fluorene $\mathbf{2 h}$ would react with formaldehyde produced by disproportionation of methanol to generate alcohol 6a, which was transformed to 9-methyl product 5a by subsequent ether formation and disproportionation.

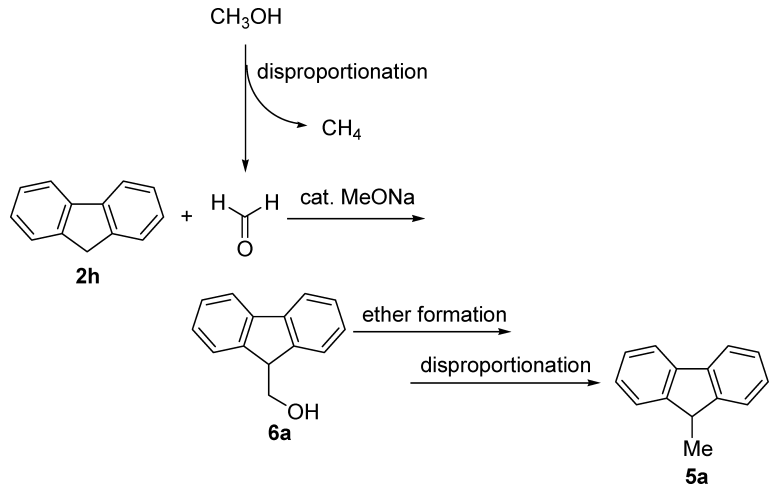

Chart 2 
Indeed, 9-methyl product 5a was obtained in $82 \%$ yield in the treatment of $\mathbf{2} \mathbf{h}$ with formaldehyde in the presence of sodium methoxide at $450{ }^{\circ} \mathrm{C}$ for $5 \mathrm{~h}$. (Eq. 5, and Table 4, entry 1). Furthermore, similar reactions of $\mathbf{2 h}$ were observed using benzaldehyde derivatives instead of formaldehyde to give $7 \mathbf{a}$ and $\mathbf{7 b}$, respectively (Table 4 , entries 2 and 3 ).

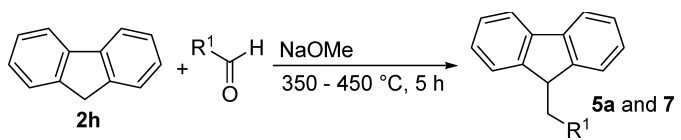

Table 4. Reaction of $\mathbf{2 h}$ with Aldehydes in the Presence of $\mathrm{NaOMe}$

\begin{tabular}{clc}
\hline \hline Entry & \multicolumn{1}{c}{$\mathrm{R}^{1}$} & Product yield $(\%)^{a)}$ \\
\hline $1^{b, c)}$ & $\mathrm{H}$ & 82 \\
$2^{d)}$ & $\mathrm{C}_{6} \mathrm{H}_{5}$ & 43 \\
$3^{d)}$ & $4-\mathrm{MeC}_{6} \mathrm{H}_{5}$ & 20
\end{tabular}

a) Isolated yield. b) An aqueous solution of formaldehyde $(37 \mathrm{w} \%)$ was used. $\quad c$ At $450{ }^{\circ} \mathrm{C} . \quad d$ ) At $350^{\circ} \mathrm{C}$

\section{Conclusion}

We found that the reduction of diarylmethanols (1) to diarylalkanes (2) proceeded in high-temperature alcohol medium, and the best result was obtained using 2-propanol at $400{ }^{\circ} \mathrm{C}$. Furthermore, we revealed that diaryl ketones (3) were reduced to diarylalkanes (2) as well, and these reductions proceeded via the MPV-reduction and disproportionation. In addition, we determined the specific reaction of fluorenes $(\mathbf{2} \mathbf{h}, \mathbf{2} \mathbf{k}, \mathbf{2 l})$ with methanol and an aldehydes at high temperature.

\section{References and Notes}

1) Review of supercritical carbon dioxide, see: Leitner W., Acc. Chem Res., 35, 746-756 (2002).

2) Review of supercritical carbon dioxide, see: Oakes R. S., Clifford A.
A., Rayner C. M., J. Chem. Soc., Parkin Trans 1, 2001, 917-941 (2001).

3) Review for sub- and supercritical water, see: Akiya N., Savage P. E., Chem. Rev., 102, 2725-2750 (2002).

4) Review for sub- and supercritical water, see: Katritzky A. R., Nichols D. A., Siskin M., Murugan R., Balasubramanian M., Chem. Rev., 101, 837-892 (2001).

5) Review for sub- and supercritical water, see: Bröll D., Kaul C., Krämer A., Krammer P., Richter T., Jung M., Vogel H., Zehner, P., Angew. Chem. Int. Ed., 38, 2998-3014 (1999).

6) For example of synthetic approach in supercritical water, see: Sato T., Sekiguchi G., Adschiri T., Arai K., Chem. Commun., 2001, 15661567 (2001).

7) For example of synthetic approach in supercritical water, see: Bryson T. A., Jennings J. M., Gibson J. M., Tetrahedron Lett., 41, 3523-3526 (2000).

8) For example of synthetic approach in supercritical water, see: Junk T., Catallo W. J., Tetrahedron Lett., 37, 3445-3448 (1996).

9) For example of synthetic approach in supercritical water, see: Yao J., Evilia R. F., J. Am. Chem. Soc., 116, 11229-11233 (1994).

10) Shaw R. W., Brill T. B., Clifford A. A., Eckert C. A., Franck E. U., Chem. Eng. News, 1991, 26-39 (1991).

11) Siskin M., Katritzky A. R., Science, 254, 231 (1991).

12) Hatano B., Kadokawa J., Tagaya H., Tetrahedron Lett., 43, 58595861 (2002).

13) Kim S., Chung N. K., Yang S., J. Org. Chem., 52, 3917-3919 (1987).

14) This part has been reported in a preliminary, see: Hatano B., Tagaya H., Tetrahedron Lett., 44, 6331-6333 (2003).

15) MPV-reduction using supercritical 2-propanol was reported. For references, see: Sominsky L., Rozental E., Gottlieb H., Gedanken A., Hoz S., J. Org. Chem., 69, 1492-1496 (2004).

16) MPV-reduction using supercritical 2-propanol was reported. For references, see: Kamitanaka T., Matsuda T., Harada T., Tetrahedron Lett., 44, 4551-4553 (2003).

17) MPV-reduction using supercritical 2-propanol was reported. For references, see: Malwitz D., Metzger J. O., Chem. Ber., 119, 3558-3575 (1986).

18) MPV-reduction using supercritical 2-propanol was reported. For references, see: Malwitz D., Metzger J. O., Angew. Chem. Int. Ed., 25, $762-763$ (1986) 